See discussions, stats, and author profiles for this publication at: https://www.researchgate.net/publication/312593226

\title{
Hydrologic pulsing promotes spatial connectivity and food web subsidies in a subtropical coastal ecosystem
}

Article in Marine Ecology Progress Series · March 2017

DOI: $10.3354 /$ meps 12060

\section{CITATIONS}

11 authors, including:

Alexandre Garcia

Universidade Federal do Rio Grande (FURG)

100 PUBLICATIONS 1,320 CITATIONS

SEE PROFILE

(6) Rodrigo Ferreira Bastos

Federal University of Pernambuco

22 PUBLICATIONS 96 CITATIONS

SEE PROFILE
382

Kirk O Winemiller

Texas A\&M University

398 PUBLICATIONS 15,643 CITATIONS

SEE PROFILE

Fabiano Corrêa

Universidade Federal de Pelotas

42 PUBLICATIONS 110 CITATIONS

SEE PROFILE

Some of the authors of this publication are also working on these related projects:

Project Biosafety and Occupational Health in Aquaculture View project

Project Food webs structure and dynamics in Southwestern Atlantic coastal systems View project 


\section{Running head:}

2 Pulse-driven subsidies in an estuarine ecosystem

4 Hydrologic pulsing promotes spatial connectivity and food web subsidies in a subtropical 5 coastal ecosystem.

7 Authors: Garcia, A.M*. ${ }^{1}$, K.O. Winemiller ${ }^{2}$, D.J. Hoeinghaus ${ }^{3}$, M.C. Claudino ${ }^{1}$, R. Bastos ${ }^{1}$, F.

8 Correa $^{1}$, S. Huckembeck, ${ }^{1}$ J. Vieira ${ }^{1}$, D. Loebmann ${ }^{1}$, P. Abreu ${ }^{1}$, and C. Ducatti ${ }^{4}$

$10{ }^{1}$ Oceanography Institute, Rio Grande Federal Universiy, Rio Grande, Rio Grande do Sul, 9620311900, BRAZIL

$12{ }^{2}$ Department of Wildlife and Fisheries Sciences and Interdisciplinary Program of Ecology and 13 Evolutionary Biology, Texas A\&M University, College Station, Texas 77843-2258, USA

$14{ }^{3}$ Department of Biological Sciences and the Advanced Environmental Research Institute,

15 University of North Texas, Denton, Texas 76203-5017, USA

$16{ }^{4}$ Paulista Júlio de Mesquita Filho State University, Stable Isotope Center for Environmental and

17 Life Sciences, Biosciences Institute, Botucatu, São Paulo 18608-000, BRAZIL.

19 \# Corresponding author

20 amgarcia.ictiofurg@gmail.com

$21+555332336539$ 


\section{Abstract}

26 Resource pulsing is a widespread phenomenon, but its effects on ecosystem dynamics are often

27 difficult to predict. Hydrological pulsing, in particular, is known to influence the structure and

28 dynamics of fluvial and coastal ecosystems, but little information is available for its effects on

29 trophic connectivity between wetlands and estuaries. In this study, we investigated the

30 hypothesis that hydrologic pulsing drives one-way trophic subsidies (e.g. suspended organic

31 matter and freshwater fish) from wetland to estuary. Our study system is a coastal lagoon with an

32 ephemeral mouth that, when closed, stores freshwater as a sustained flood pulse that is

33 subsequently released when a connection with the sea is reestablished. We monitored isotopic

34 composition of consumers and food sources over the course of an entire flood pulse to infer

35 trophic linkages and spatial subsidies. Before the flood peak (April and May), freshwater and

36 estuarine zones were largely dependent on local primary production sources (seston and $\mathrm{C}_{3}$

37 plants vs. $\mathrm{C}_{4}$ plants and microphytobenthos, respectively), essentially functioning as

38 disconnected compartments. A sustained pulse of freshwater inflow (June to August) induced

39 greater habitat connectivity and a net flow of biomass and energy from the freshwater zone into

40 the estuarine zone. The opening of the lagoon outlet channel abruptly terminated the flood pulse

41 and reduced freshwater subsidies to estuarine consumers, and both zones returned to dependence

42 on autochthonous production. Our findings contribute to current concerns that artificial opening

43 of sandbars in coastal lagoons alters natural ecological dynamics with significant effects on

44 biodiversity and ecosystem processes. 
46 Keywords: basal resource, Bayesian mixing model, biomass assimilation, estuary, hydrologic

47 connectivity, production source, salinity, trophic ecology

48

49

50

51

52

53

54

55 


\section{Introduction}

Food web dynamics are influenced not only by consumer-resource interactions, but also

58 by environmental variation that directly affects ecosystem productivity, habitat suitability, and

59 other factors affecting organism fitness and population growth (Winemiller \& Layman 2005).

60 Further complicating our ability to predict dynamics in response to environmental drivers is the

61 fact that perceived patterns of variation are influenced by temporal and spatial scales of analysis

62 (Petraitis \& Latham 1999). Most, and probably all, ecosystems are subject to abiotic factors that

63 pulse. Resource pulses, in particular, are defined as discrete, significant increases in resource

64 availability over intervals of time and/or space (Yang et al. 2008). Environmental seasonality

65 affects local population dynamics and species interactions, but also can have regional effects

66 when pulsing factors induce mass migrations or synchrony among regional populations

67 (Leibhold et al. 2004). For example, Krenz et al. (2011) showed how coastal upwelling

68 influenced by the El Niño Southern Oscillation affects food web subsidies within intertidal

69 ecosystems over a large region. Resource subsidies associated with pulsing environmental

70 factors strongly influence bottom-up (e.g. a fertilizer effect) and top-down (consumer control)

71 effects in food webs of arid islands (Polis et al. 1997, Spiller et al. 2010).

72 Pulsing can induce responses that reverberate throughout the food web (Yang et al. 2008).

73 Mass spawning by corals and reef fishes in response to lunar and oceanographic cues produces

74 huge subsidies for planktivores (Pratchett et al. 2001), which can have long-term effects on

75 fitness of the latter (McCormick 2003). Regional insect outbreaks in response to favorable

76 climatic conditions can devastate plant biomass (Mattson \& Addy 1975) while subsidizing

77 insectivores (Yang 2004).Seasonal migrations can create food web subsidies at the landscape

78 scale (Polis et al. 2004). For example, the decomposing carcasses of post-spawn anadromous 
79 salmon provide a pulse of marine-derived nutrients that stimulates primary production not only

80 within oligotrophic streams, but also riparian terrestrial ecosystems (Naiman et al. 2002).

81 Theoretical models indicate diverse responses to pulsing that range from transient population

82 dynamics that may or may not influence species coexistence, to tipping the dynamics governing

83 alternative stable states of ecosystems (Ostfeld \& Keesing 2000, Holt 2008; Petersen et al. 2008).

84 Hydrologic changes, in particular, can trigger ecosystem pulsing that affects the structure

85 and dynamics of fluvial and coastal ecosystems (Winemiller 1990, Poff et al. 1997, DeAngelis et

86 al. 2005, Childers 2006, Warfe et al. 2011). Fish dynamics in hydrologically pulsed wetland

87 ecosystems monitored across long time scales (e.g. Florida's Everglades) are strongly associated

88 with seasonal cycles in precipitation and water depth that cascade to other components of the

89 food web (DeAngelis et al. 1997, Childers 2006).

90 In southeastern Brazil, inter-annual and seasonal variation in precipitation drives changes

91 in hydrology and salinity gradients that, in turn, affect the composition of local fish assemblages

92 within coastal lagoons (Garcia et al. 2003, Garcia et al. 2004). A suitable ecosystem model for

93 evaluating hydrologic pulsing effects on spatial food web subsidies between freshwater and

94 estuarine systems in this region is the Lagoa do Peixe National Park (LPNP). Ecological

95 conditions within LPNP are influenced not only by intra-annual variations in freshwater inflow,

96 but also by ephemeral connections with the sea. Freshwater draining from the coastal plain is

97 stored within the lagoon as a sustained flood pulse and then released over a relatively short

98 period when a connection with the sea is established either (i) naturally by inflows or (ii)

99 artificially by mechanical excavation (Lanés et al. 2015). Thus, hydrology induces a freshwater

100 flood pulse that causes aquatic ecosystem expansion with greater connectivity between the 
101 freshwater wetland and the estuarine zone and conditions promoting input of freshwater basal

102 production sources and consumer taxa into the estuary.

103 We hypothesized that hydrologic pulsing influences food web dynamics along the

104 longitudinal fluvial gradient via one-way trophic subsidies (e.g. passive transport of suspended 105 organic matter and dispersal of freshwater fish) from wetland to estuary. We used stable isotope 106 methods to test this hypothesis based on extensive temporal and spatial sampling of production

107 sources and consumers at locations along the longitudinal fluvial gradient, and used a Bayesian

108 mixing model to estimate probability distributions for assimilation of alternative production

109 sources. Stable isotope analysis (SIA) is commonly used to reconstruct trophic links connecting

110 food web components across spatial (Hoeinghaus et al. 2011, Claudino et al. 2015) and temporal

111 (Claudino et al. 2013, Garcia et al. in press) scales, and several authors have used SIA to test

112 effects of hydrologic changes on food web organization and spatial subsidies among ecosystems

113 (Jardine et al. 2012, Abrantes et al. 2013, Kaymak et al. 2015, Ou \& Winemiller 2016). In

114 contrast with most previous studies that used seasonal or before-and-after sampling designs, our

115 study analyzed a time-series of samples taken over frequent, short intervals, which enabled us to

116 view food web structure like a movie rather than a snapshot. This analysis provided a basis for

117 estimating the timing and magnitude of a spatial food web subsidy to estuarine consumers.

119 Material and methods

120 Study area

121 The Lagoa do Peixe National Park (LPNP) has an area of $344 \mathrm{~km}^{2}$ and is situated along

122 the coastal plain of Rio Grande do Sul, the southernmost state in Brazil. This coastal plain is

123 characterized by a flat topography, low altitude (<20 masl) and low tidal range $(\sim 0.5 \mathrm{~m})$ (Fig. 1$)$. 
124 Lagoa do Peixe is a shallow coastal lagoon $(<50 \mathrm{~cm}$, except its channel) surrounded by

125 freshwater wetlands (Maltchik et al. 2010), except for its eastern border where sand dunes are

126 prevalent (Fig. 1). The lagoon has a narrow outlet to the sea that is blocked from

127 February/March to August/September each year by sand dunes until freshwater inflows, usually

128 from winter rainfall, establish a connection. If the seasonal connection with the sea is not

129 established naturally, earth-moving machinery is used to construct an outlet channel (200 m long,

$13040 \mathrm{~m}$ wide, $1.5 \mathrm{~m}$ deep) during late winter (August-September). The overall dimensions of both

131 artificial and natural channels are similar. This periodic opening of the outlet is done to promote

132 the entrance of marine shrimp larvae into the lagoon to favor commercial fisheries and also to

133 drain water from the floodplain to increase pasture for livestock ranching (Lanés et al. 2015).

134 The LPNP has a humid subtropical climate, with mean temperatures ranging from $14.6^{\circ} \mathrm{C}$

135 to $22.2^{\circ} \mathrm{C}$, a mean annual temperature of $17.5^{\circ} \mathrm{C}$, and annual precipitation in the study area

136 ranges from 1,150 to $1,450 \mathrm{~mm} \mathrm{yr}^{-1}$, with an annual mean of $1,250 \mathrm{~mm} \mathrm{yr}^{-1}$. Prior studies on

137 estuarine systems approximately $100 \mathrm{~km}$ south of the LPNP have shown that rainfall anomalies

138 cause hydrological changes that affect estuarine and freshwater fish assemblages (Garcia et al.

139 2004). To assess potential influence of climatic variation on ecological dynamics, temperature

140 and rainfall data were obtained from two meteorological stations (Rio Grande and Mostardas)

141 near the study area (Fig. 1), and the status of the lagoon connection with the sea was monitored

142 throughout the study. Rainfall varied seasonally, with two periods of high rainfall: May to

143 August 2008 and January to March 2009. The former wet period coincided with a closed lagoon

144 mouth, which occurred from April to August 2008. At the estuarine site in particular, water

145 flooded over the marginal areas during wet periods, increasing hydrological exchanges with

146 freshwater wetlands. Average air temperature varied seasonally, with lowest values during the 
147 austral winter (14.1 $\mathrm{C}$ in June) and highest values in summer (23.7 $\mathrm{C}$ in February). Based on

148 this climatic variation, we defined flooded and non-flooded phases of the hydrologic pulse in 149 order to evaluate our initial hypothesis (Fig. 1).

Field collections and sample processing

Samples were obtained monthly from April 2008 to May 2009 (with the exception of

153 September 2008 and March 2009) in three regions along the main longitudinal axis of the LPNP:

154 1) a freshwater wetland located near the northern limit of the park, 2) the upper-middle reach of

155 the lagoon that encompasses an ecotone between estuarine and freshwater zones, and 3) the 156 middle reach of the lagoon near the ephemeral connection with the sea (Fig. 1). These sites are

157 subsequently referred to as freshwater wetland, estuarine zone and lagoon mouth, respectively.

Fish were caught using four fishing gears (gillnets, beach seine, beam trawl, dipnet)

159 during each monthly survey. To catch larger fishes (>200 mm total length), two gillnets (4 x $2 \mathrm{~m}$,

160 comprised by panels with different mesh sizes of 15, 20, 30 and $35 \mathrm{~mm}$ ) were deployed in the

161 channel (2.0 - $2.5 \mathrm{~m}$ deep). One to two beach seine ( $9 \mathrm{~m}$ long, $2.4 \mathrm{~m}$ high, mesh size $13 \mathrm{~mm}$

162 wings and $5 \mathrm{~mm}$ center) hauls were made in unvegetated nearshore areas. Densely vegetated

163 marginal habitats were sampled with three hauls of the beam trawl (mouth $=1 \mathrm{x} 1 \mathrm{~m}$, mesh $=5$

$164 \mathrm{~mm}$ ) and dip netting for approximately $15 \mathrm{~min}$. Beach seine and beam trawl hauls and dip

165 netting were conducted in shallower waters $(<1.5 \mathrm{~m})$ and were effective in capturing smaller

166 species $(<50 \mathrm{~mm})$, including those that take refuge in structurally complex habitats. Sampling

167 with multiple gear types provides a more representative sample of the fish assemblage, especially

168 when the ecosystem is comprised by multiple habitat types with differing complexities and

169 species of various sizes and behaviors (Rozas \& Minello 1997, Chick et al., 2004, Garcia et al. 
170 2006). Representative macroinvertebrates, such as adult and immature aquatic insects,

171 gastropods, polychaete worms, shrimps and crabs, were collected at each study site.

172 Samples of microphytobenthos, seston (phytoplankton and suspended fine particulate

173 organic matter), and leaves from floating, emergent and submerged macrophytes were collected

174 at each site during each survey. This material was used for determination of the isotopic

175 composition of major basal production sources. Macrophytes were collected by hand, samples

176 of microphytobenthos were obtained by carefully removing the thin upper layer of flocculent or

177 consolidated biofilm from substrates, and seston samples were obtained by filtering water

178 through a pre-combusted $\left(450^{\circ} \mathrm{C}, 4 \mathrm{~h}\right)$ Whatman glass fiber filter (GF/F) using a manual pump.

179 Immediately after collection, all specimens were placed on ice for transport to the

180 laboratory where they were stored frozen. After thawing, fish were weighed $(\mathrm{g})$, measured (mm

181 total length, TL) and dissected to extract approximately $5 \mathrm{~g}$ of dorsal muscle tissue for isotopic

182 analysis. For fish $<50 \mathrm{~mm}$ TL, a composite sample was obtained by combining muscle tissue

183 from 5-15 conspecifics from the same site. Gastropods, shrimps and crabs were dissected, and a

184 sample of muscle tissue was extracted for stable isotope analysis. Due to their small sizes,

185 polychaetes and aquatic insects were processed as whole specimens. Tissue samples from fish

186 and macroinvertebrates were inspected and any significant non-muscle material (e.g. bone, scales,

187 exoskeleton) was removed before the samples were rinsed with distilled water, placed in sterile

188 Petri dishes, and dried in an oven at $60^{\circ} \mathrm{C}$ until attainment of a constant weight (minimum of 48

189 h). Dried samples were ground to a fine powder with a mortar and pestle and stored in clean

190 Eppendorf tubes. Sub-samples were weighed to 6-10 mg, pressed into Ultra-Pure tin capsules

191 (Costech, Valencia, CA), and sent to the Centro de Isótopos Estáveis, Universidade Estadual

192 Paulista (UNESP) for measurement of stable isotope ratios $\left({ }^{13} \mathrm{C} /{ }^{12} \mathrm{C}\right.$ and $\left.{ }^{15} \mathrm{~N} /{ }^{14} \mathrm{~N}\right)$. Results are 
193 reported as parts per thousand (\%o) differences from a corresponding standard: $\delta^{\mathrm{H}} \mathrm{X}=\left[\left(\mathrm{R}_{\text {sample }} /\right.\right.$

$\left.\left.194 \mathrm{R}_{\text {standard }}\right)-1\right] \times 1000$, where $\mathrm{X}$ is a particular element (C, carbon or $\mathrm{N}$, nitrogen), the superscript $\mathrm{H}$

195 denotes the heavy isotope mass of the given element $\left({ }^{13} \mathrm{C},{ }^{15} \mathrm{~N}\right)$ and $\mathrm{R}$ is the ratio of the heavy

196 isotope to the light isotope for the element $\left({ }^{13} \mathrm{C} /{ }^{12} \mathrm{C},{ }^{15} \mathrm{~N} /{ }^{14} \mathrm{~N}\right)$. Standards were carbon in the

197 PeeDee Belemnite and molecular nitrogen in air. Standard deviations of $\delta^{13} \mathrm{C}$ and $\delta^{15} \mathrm{~N}$ replicate

198 analyses were $0.14 \%$ and $0.13 \%$, respectively.

200 Data analysis

201 For some analyses, fishes were pooled into five functional guilds based on prior

202 classification proposed by Garcia et al. (2001) and also considering Myers' (1938) model of

203 primary- and secondary-division freshwater fishes, as follows: 1) estuarine resident species that

204 typically occur and breed within the estuary; 2) estuarine dependents that are marine or

205 freshwater spawning species found in large numbers within the estuary during certain periods of

206 their life cycle; 3) marine vagrants typically inhabiting marine habitats and rarely occurring

207 within the estuary; 4) primary freshwater fishes with no tolerance to salinity that are confined to

208 freshwater; and 5) secondary freshwater fishes with some salinity tolerance that may enter

209 brackish water occasionally. Also, due to consistent differences in retention of ${ }^{13} \mathrm{C}$ by plants

210 using the Calvin cycle $\left(\mathrm{C}_{3}\right)$ and Hatch-Slack cycle $\left(\mathrm{C}_{4}\right)$ photosynthetic pathways (Marshall et al.

211 2007), sampled macrophytes were pooled and analyzed as two groups, $\mathrm{C}_{3}$ vs. $\mathrm{C}_{4}$, according to

212 the literature (Marshall et al. 2007), the range of $\delta^{13} \mathrm{C}$ values observed in this study and previous

213 research in nearby coastal lagoon ecosystems (Garcia et al. 2007, Hoeinghaus et al. 2011). $\mathrm{C}_{3}$

214 plants tend to have significantly lower average carbon stable isotope ratios $(\sim-27 \%$ o $)$ than $\mathrm{C}_{4}$

215 plants $(\sim-4 \%$ ) mainly due to differences in the enzymes involved in carbon fixation during 
216 photosynthesis (Marshall et al. 2007). Abundance patterns of these groups shift along the salinity

217 gradient of the study site, with $\mathrm{C}_{3}$ being the dominant aquatic macrophytes in the freshwater

218 wetland and $\mathrm{C}_{4}$ plants dominant in the estuarine/marine sites (Knak 2004, Rolon et al. 2011).

219 Bi-plots of $\delta^{15} \mathrm{~N}$ and $\delta^{13} \mathrm{C}$ values of primary producers and organic sources, invertebrates

220 and fishes were used to evaluate patterns of isotopic variation across spatial and temporal scales.

221 Sources of organic carbon assimilated by consumers are indicated by proximity between carbon

222 isotope ratios $\left(\delta^{13} \mathrm{C}\right)$ of consumers and their food sources, whereas trophic position of each

223 consumer is indicated by the relative position of their nitrogen isotope ratios $\left(\delta^{15} \mathrm{~N}\right)$ in relation to

224 an isotopic baseline (Peterson \& Fry, 1987). Analysis of variance (ANOVA) was used to

225 compare average $\delta^{13} \mathrm{C}$ and $\delta^{15} \mathrm{~N}$ values of sources and consumers among study sites and, for

226 fishes only, among months. When a significant main effect was observed, pairwise comparisons

227 of site means were performed using Newman-Keuls post-hoc procedure. Normality and

228 homogeneity of variances were evaluated by the Kolmogorov-Smirnov and Cochran tests,

229 respectively (Zar 1984).

230 To estimate relative contributions of basal production sources to fish assemblages of the

231 freshwater wetland, estuarine zone and lagoon mouth, we employed Bayesian mixing model with

232 four basal production sources as end-members (seston, microphytobenthos, $\mathrm{C}_{3}$ and $\mathrm{C}_{4}$ plants)

233 using data specific to each site. Mixing models were run using the Stable Isotope Analysis in R

234 (SIAR) package in R statistical software (R Core Team 2012), which employs a Bayesian

235 approach that incorporates uncertainties associated with sample variability and trophic

236 enrichment on the assumption they are normally distributed (Parnell et al. 2010). Each mixing

237 model was fit via a Markov chain Monte Carlo (MCMC) method that generate simulations of

238 plausible values of dietary proportions consistent with the data using a Dirichlet prior 
239 distribution (Parnell et al. 2010). Each model was run based on 500,000 iterations, discarding the

240 first 50,000, and considering a non-informative prior to guide the dietary proportion simulations.

241 Upper and lower credibility intervals $(95,75$ and 50\%) were used to describe the range of

242 feasible contributions for each food source to the consumer (Parnell et al. 2010).

243 In order to quantify food web subsidies occurring due to movement of carbon sources

244 from the freshwater wetland into the estuarine zone, we ran five-end-member SIAR mixing

245 models to estimate, on a monthly basis, the relative contribution of freshwater- and estuarine-

246 derived sources for estuarine resident fishes (silversides Atherinella brasiliensis and Odonthestes

247 argentinensis) and individuals of primary freshwater fish species that were collected within the

248 estuarine zone during the hydrologic pulse. Importantly, silversides are not piscivorous, and thus

249 assimilation of freshwater-derived sources by these estuarine-resident taxa is not by consumption

250 of freshwater fishes that moved into the estuarine zone. We used average values of carbon and

251 nitrogen isotope ratios of seston and $\mathrm{C}_{3}$ plants collected in the wetland, and microphytobenthos,

$252 \mathrm{C}_{4}$ plants and seston collected in the estuary as representative freshwater- and estuarine-derived

253 basal production sources. We chose freshwater seston and $\mathrm{C}_{3}$ plants (mostly floating

254 macrophytes) because these basal sources are transported from the freshwater wetland into the

255 estuarine zone during floods, which create hydrologic connectivity between regions. Estuarine

256 sources included in this model were based on the four-end-member mixing model that identified

257 the primary sources assimilated by the estuarine fish assemblage. Mixing models were computed

258 assuming the silversides are two trophic levels above the basal production sources, and we used

259 values of $0.54 \% \pm 1.23$ and $2.54 \% \pm \pm 0.11$ to correct for trophic fractionation of isotopic ratios of

260 carbon and nitrogen, respectively (Vanderklift \& Ponsard 2003). 
274 lagoon mouth zones $\left(\delta^{13} \mathrm{C}:-13.8 \% \pm 2.4, \delta^{15} \mathrm{~N}: 13.3 \% \pm 2.1\right)($ Fig, 2 , Table S1). Overall, 275 invertebrates (e.g. crabs, shrimps, polychaete worms), macrophytes $\left(\mathrm{C}_{3}\right.$ and $\left.\mathrm{C}_{4}\right)$ and other 276 potential food resources (seston, microphytobenthos) showed similar trends. Specifically, both $277 \quad \delta^{13} \mathrm{C}$ and $\delta^{15} \mathrm{~N}$ values significantly increased from the freshwater wetland to the lagoon mouth 278 (Fig. 2, Table S1).

\section{Results}

A total of 684 samples representing 52 fish species was obtained in the freshwater wetland ( $n=352)$, estuarine zone $(n=187)$ and lagoon mouth $(n=145)$ between April 2008 and May 2009 for analysis of carbon and nitrogen stable isotope ratios (Table S1). Local fish assemblages showed a gradual zonation in species composition across the freshwater-estuarine gradient. Primary- and secondary-freshwater fishes were restricted to freshwater wetland and estuarine zones, with the only exception Jenynsia multidentata (secondary freshwater species), which occurred at all three sites. In contrast, estuarine residents, estuarine dependents and marine vagrants were captured only within the estuarine zone and the lagoon mouth (Table S1). At the assemblage scale, there was a significant trend in $\delta^{13} \mathrm{C}$ and $\delta^{15} \mathrm{~N}$ along the freshwater to estuarine gradient, with lower values in freshwater $\left(\delta^{13} \mathrm{C}:-26.3 \% \pm \pm 2.86, \delta^{15} \mathrm{~N}\right.$ : $7.5 \% \pm \pm 1.5)$ and much higher values in the estuarine $\left(\delta^{13} \mathrm{C}:-15.7 \% 0 \pm 3.4, \delta^{15} \mathrm{~N}: 10.4 \% \pm \pm 1.8\right)$ and

For fish, quantitative estimates from Bayesian isotopic mixing-models revealed that seston and $\mathrm{C}_{3}$ plants ( 0.53 to 0.69 and 0.23 to 0.44 , respectively) were the basal sources assimilated in greatest proportions by fish inhabiting the freshwater wetland. Conversely, within the two mixohaline sites (estuarine zone and lagoon mouth), $\mathrm{C}_{4}$ plants and microphytobenthos were the basal carbon sources assimilated in greatest proportions. For the estuarine zone, in particular, $\mathrm{C}_{4}$ plants had a much greater contribution to fish biomass ( 0.70 to 0.83 ) compared 
285 with $\mathrm{C}_{3}$ plants (0.08 to 0.21$)$, and $\mathrm{C}_{4}$ plants and microphytobenthos were the basal carbon

286 sources with highest contributions near the lagoon mouth ( 0.53 to 0.71 and 0.07 to 0.42 ,

287 respectively) (Fig. 2, right panel).

288 Monthly analysis of the isotopic composition of fish assemblages revealed important

289 changes in the spatial trend in average $\delta^{13} \mathrm{C}$ across study sites (Fig. 3), which coincided with the

290 effect that the closure of the lagoon's connection with the sea has on the flood dynamics of this

291 system. During the flooding episode recorded between April and October 2008, mean fish $\delta^{13} \mathrm{C}$

292 values across all sites were significantly lower (-23.5\%) compared with those recorded during

293 the non-flooded period $(-20.0 \%)\left(\mathrm{F}_{1,687}=32.28, \mathrm{p}<0.00\right)$. When functional guilds were taken

294 into account, we observed that this difference was primarily due to the occurrence of salinity-

295 intolerant, primary freshwater fishes, especially small characids (Astyanax eigenmanniorum,

$29659.7 \pm 11.8 \mathrm{~mm}$ TL; A. fasciatus, $35.7 \pm 8.8 \mathrm{~mm}$ TL; Cheirodon interruptus, $32.4 \pm 6.0 \mathrm{~mm}$ TL)

297 and poeciliids (Phalloceros caudimaculatus, $28.6 \pm 8.7 \mathrm{~mm}$ TL), that occurred in the estuarine

298 zone from July to November (Fig. 3). Fish collected from the estuary in July had lower $\delta^{13} \mathrm{C}$

299 values (-21.6\%o), but the isotopic composition of these primarily freshwater species increased

$300 \quad\left(\mathrm{~F}_{4,38}=7.51, \mathrm{p}<0.00\right)$ nearer to the estuarine site until approaching values $(-17.7 \%)$ similar to

301 those observed for estuarine-dependent fishes. Estuarine-resident fishes also showed significant

302 differences in their average $\delta^{13} \mathrm{C}$ values during the flood period $\left(\mathrm{F}_{1,106}=108.37, \mathrm{p}<0.00\right)$, and

303 had lower values (-18.7\%o) when compared with the non-flooded period (-13.5\%o) (Fig. 3).

304 Temporal variation in $\delta^{13} \mathrm{C}$ during flooded vs. non-flooded conditions (Appendix B) also

305 occurred for some basal sources, such as microphytobenthos $\left(F_{1,18}=6.47, p<0.02\right)$ and seston

$306\left(\mathrm{~F}_{1,17}=11.44, \mathrm{p}<0.00\right)$, which had lower $\delta^{13} \mathrm{C}$ during flooded $(-21.8 \%$ and $-22.6 \%$, respectively $)$

307 vs. non-flooded (-17.2\% and $-18.4 \%$, respectively) conditions. Average $\delta^{13} \mathrm{C}$ values of other 
sources ( $\mathrm{C}_{3}$ and $\mathrm{C}_{4}$ plants) did not change significantly between flooding conditions $\left(\mathrm{F}_{1,16}=\right.$ $0.0656, \mathrm{p}<0.80$ and $\mathrm{F}_{1,5}=0.0057, \mathrm{p}<0.94$, respectively) (Appendix B). Mixing models revealed that freshwater-derived basal sources $\left(\mathrm{C}_{3}\right.$ plants and seston)

311 contributed to estuarine residents (silversides A. brasiliensis and O. argentinensis) during flood 312 conditions (April through July) (Fig. 4, left panel). Contributions of these sources were nearly

313 zero in April, but gradually increased to up to $40 \%$ in June and July. Over the same period,

314 contribution of estuarine-derived basal sources to estuarine fish biomass declined. However, two

315 months after the opening of the lagoon mouth and cessation of flood conditions and hydrologic

316 connectivity with the freshwater wetland, the contribution of freshwater-derived basal sources to

317 estuarine resident fish decreased, and $\mathrm{C}_{4}$ plants and microphytobenthos again were the main

318 sources supporting estuarine resident fishes (Fig. 4, left panel). Primary freshwater fishes, such

319 as characids and poeciliids, assimilated carbon derived mostly from seston and $\mathrm{C}_{3}$ plants in the

320 freshwater wetland. Conspecifics caught within the estuarine zone during the late flooding

321 period (July- August) assimilated freshwater- and estuarine-derived basal sources in similar

322 amounts. Similar to estuarine-resident fishes, the percent contribution of estuarine-derived

323 sources (microphytobenthos and $\mathrm{C}_{4}$ plants) to these freshwater species inhabiting the estuarine

324 zone increased to up to $69 \%$ following cessation of flood conditions (Fig. 4, right panel).

\section{Discussion}

Pulsing hydrology in Lagoa do Peixe affected both habitat productivity and habitat

328 connectivity which together resulted in trophic subsidies from the freshwater wetland to

329 estuarine consumers. This subsidy occurred via passive transport of basal sources (e.g. terrestrial

330 detritus in the form of fine particulate organic matter) as well as dispersal by freshwater fishes 
331 and probably other freshwater taxa along the fluvial gradient. Seston (phytoplankton plus

332 suspended particulate organic matter of undetermined origin) from the freshwater wetland was

333 apparently transported in significant quantities into the estuary during the flood pulse. The

334 assimilation of this isotopically distinct seston (approximately $4 \%$ and $6 \%$ lower $\delta^{13} \mathrm{C}$ than

335 seston from the estuarine zone and lagoon mouth, respectively) by estuarine primary consumers

336 (e.g. zooplankton) and their subsequent consumption by fish could explain why we observed an

337 average reduction of approximately $5 \%$ in carbon isotope ratios of estuarine fishes (Odonthestes

338 argentinesis and Atherinella brasiliensis) during the flood period. Carbon isotope ratios of

339 estuarine fish gradually shifted back to typical estuarine isotopic values observed during pre-

340 flooding conditions, suggesting their prey transitioned back to assimilating locally produced

341 estuarine seston.

342 In addition to passive transport of seston during flooding conditions, food web subsidies

343 also occurred via animal dispersal from the wetland into the estuary. Animal dispersal in fluvial

344 systems is often directional, either by downstream drift or upstream swimming against prevailing

345 current (Flecker et al. 2010, Oliveira et al. 2014). For example, anadromous fish that ascend

346 rivers to spawn have been shown to deliver large amounts of nutrients from excretion and

347 carcass decomposition that subsidize freshwater and riparian ecosystems by enhancing primary

348 production (Naiman et al. 2002, Koshino et al. 2013). Juvenile marine fish that migrate into

349 small coastal streams in Brazil excrete marine-derived nutrients and are consumed by resident

350 freshwater piscivores (Oliveira et al. 2014), thereby subsidizing the base and top of the food web

351 simultaneously. During the Lagoa do Peixe flood pulse, salinity-intolerant primary freshwater

352 fishes (e.g. small characins such as A. eigenmanniorum, A. fasciatus, and C. interruptus) moved 
353 into the estuarine region and began to assimilate material derived from local basal production

354 sources.

355 In this system, these species generally consume cladocerans, other microcrustacea, algae 356 and vascular plant fragments (FC, unpublished stomach contents data). Consumption of locally357 produced microcrustacea and vegetation would explain the spatial and temporal dynamics in 358 isotopic values for these species, especially for those specimens sampled after the opening of the 359 lagoon mouth. In addition to assimilating significant amounts of estuarine resources during their 360 brief periods of residence in the estuary, these freshwater fishes contribute to nutrient dynamics 361 via excretion and also delivered a pulse of biomass and energy that can be exploited by avian 362 (Bugoni et al. 2005) and mammalian (Colares \& Waldemarin 2000) predators. Studies of other 363 coastal lagoons have demonstrated that a great diversity of freshwater fishes from different 364 trophic guilds (e.g. detritivores, zoobenthivores, piscivores) can colonize estuarine zones during 365 high freshwater discharges (Garcia et al. 2003). However, their potential effects on fitness, 366 feeding habits and survival of estuarine competitors and predators as well as overall effects to 367 estuarine food web organization remain largely unknown.

368 Estimates of spatial food web subsidies generally have involved asymmetric productivity 369 across aquatic-terrestrial or marine-terrestrial ecotones, with the more productive habitat being a 370 net donor (e.g. coastal marine systems, riparian forests) and less productive habitat being a net 371 recipient (e.g. arid islands, forest streams) (Polis et al. 2004). We are unaware of prior evidence 372 for reciprocal subsidies between aquatic habitats with similar productivity, such as freshwater 373 wetlands and estuaries. Whether or not inputs of wetland-derived allochthonous organic matter 374 and freshwater fish into estuaries induce trophic cascades probably depends on the relative 375 productivity of the two systems and the degree to which there are reciprocal subsidies. Potential 
376 bottom-up and top-down effects could be further elucidated by field experiments. For example,

377 Nakano and colleagues conducted field experiments and dietary analyses to estimate reciprocal

378 subsidies across aquatic-terrestrial ecotones and their influence on trophic cascades (Nakano et al.

379 1999, Nakano \& Murakami 2001). Baxter et al. (2004) demonstrated how habitat alteration and

380 introduction of alien predators suppressed flows of resources across ecotones and associated

381 reciprocal subsidies.

382 Fish guilds responded differently to the pulse of freshwater inflow and degree of

383 connectivity with the sea. Estuarine-dependent (e.g. Brevoortia pectinata, Micropogonias

384 furnieri, Paralichthys orbignyanus) and marine-vagrant (e.g. Diapterus rhombeus, Eucinostomus

385 melanopterus, Menticirrhus littoralis, Trachinotus marginatus, Ulaema lefroyi) fishes were

386 absent in mixohaline zones (estuary, lagoon mouth) during the latter stages of flooding when

387 characids, poeciliids and other freshwater fishes were prevalent. Marine fishes responded to the

388 freshwater pulse by moving southward toward the sea, but they could not exit the lagoon because

389 sand dunes blocked the outlet. Several species from the marine guild (e.g. croakers, mullets,

390 silversides) were observed in high densities within shallow pools along the margins of the outlet

391 zone. Mass mortality of marine species sometimes occurs during periods of drought as well as

392 periods of freshwater expansion into mixohaline zones (AMG, personal observation) and would

393 explain the absence of estuarine-dependent and marine-vagrant fish when the lagoon's mouth

394 was closed. Similar to other coastal lagoons in the region (Garcia et al. 2012), marine fishes

395 returned to the mixohaline zones soon after the connection to the sea was opened with machinery.

396 Because we did not sample marine habitat outside the lagoon outlet, we can only speculate about

397 effects of estuarine discharge of resources on the nearshore marine food web. Using stable

398 isotope analysis, Savage et al. (2012) showed that freshwater primary production subsidizes 

415 and time.

Our findings provide evidences that human interference with the connectivity of coastal wetlands, lagoons and the sea can greatly affect food web dynamics, including trophic subsidies among their compartments. Mechanical opening the lagoon outlet terminated the flood pulse and

suspension-feeding bivalves in coastal waters of New Zealand when high flow pulses transport material from the estuary to the adjacent coast.

High resolution temporal sampling of food web components was crucial to reveal how pulsed freshwater inflows affect trophic subsidies between zones of a coastal lagoon ecosystem. All estuarine systems experience hydrologic pulsing, with patterns varying from seasonal (e.g. wet/dry tropics, temperate regions with spring snowmelt) to highly variable and relatively unpredictable regimes (dryland rivers). Appropriate sampling designs are required to reveal spatiotemporal patterns of food web dynamics caused by hydrologic pulsing (Yang et al. 2008). Resource pulses occur at multiple scales, and a local subsidy for one species (e.g. short-lived, sedentary organism) may be insignificant for another (e.g. long-lived, migratory organism) (Zackrisson et al. 1999, Yang et al. 2008). Therefore, in order to quantify resource pulses, it is crucial to define relevant spatial and temporal scales matching resource-consumer interactions. Because we sampled food web components with greater frequency (monthly) compared with most prior studies (e.g. pre- vs. post-flood or seasonal sampling), our analysis was able to reveal the timing, magnitude and duration of trophic subsidies along the longitudinal fluvial gradient. Analysis of fish guilds also allowed us to identify pulses at ecologically relevant scales in space reduced freshwater subsidies delivery to the estuarine zone, but it also allowed estuarinedependent species to access critical habitat for early life stages. Excavation of the Lagoa do Peixe outlet channel has been done multiple times over the past 150 years to allow entrance of 
422 shrimp (Farfantepenaeus paulensis) from the sea into the lagoon and to drain water from the

423 floodplain to increase pasture for cattle (Lanés et al. 2015). Ecological responses to artificial

424 connections between coastal lagoons and marine systems are difficult to predict, and fish species

425 diversity may decline (Saad et al. 2002), increase (Griffiths 1999), or change little (Lanés et al.

426 2015). There is general concern that artificial opening of sandbars in coastal lagoons alters

427 natural ecological dynamics with potential negative effects on biodiversity and ecosystem

428 services (Griffiths 1999, Saad et al. 2002). Our study contributes to this discourse by

429 demonstrating how the timing of freshwater inflows and the outlet opening affect food web

430 dynamics in different regions of the lagoon system.

$431 \quad$ Future studies of coastal ecotones could examine the influence of pulsing allochthonous

432 inputs on the distribution of trophic interactions of varying strength within the regional food web.

433 Prior theoretical and empirical work suggests that greater proportions of weak trophic

434 interactions enhance stability in species-rich food webs, and strong trophic interactions promote

435 destabilizing oscillations (Kokkoris et al. 2002, Cross et al. 2013). Landscape mosaics, including

436 fluvial ecosystems and other ecotones, might have greater proportions of weak links within the

437 regional food web when there is periodic exchange of organisms among habitat compartments

438 (Bellmore et al. 2015). Research that combines comparative and experimental approaches to

439 estimate interaction strength could test this hypothesis and further elucidate ecological responses

440 to pulsing hydrology and food web subsidies.

442 Acknowledgements

443 This study received financial support from Brazil's Conselho Nacional de Desenvolvimento

444 Científico e Tecnológico, CNPq (Grant No. 482920/2007-6) and International Foundation of 
445 Science, IFS (Grant No.A/4419-1). AMG acknowledges fellowship support from CNPq 446 (305888/2012-9) and the ICMBIO for providing permit (14523-2 and 14523-4) for sample

447 collections. KOW acknowledges support from the US National Science Foundation (DEB 4481257813 and IGERT 0654377). This is a contribution of the Grupo de Análises de Isótopos 449 Estáveis em Ambientes Aquáticos (GAIA/CNPq).

\section{Literature Cited}

453 Abrantes KG, Barnett A, Bouillon S (2013) Stable isotope-based community metrics as a tool to 454 identify patterns in food web structure in east African estuaries. Funct Ecol 28:270-282

455 Baxter CV, Fausch KD, Murakami M, Chapman PL (2004) Fish invasion restructures stream and 456 forest food webs by interrupting reciprocal prey subsidies. Ecology 85:2656-2663

457 Bellmore JR, Baxter CV, Connolly PJ (2015) Spatial complexity reduces interaction strengths in 458 the meta-food web of a river floodplain mosaic. Ecology 96:274-283

459 Bugoni L, Cormons TD, Boyne AW, Hays H (2005) Feeding Grounds, Daily Foraging Activities, 460 and Movements of Common Terns in Southern Brazil, Determined by Radio-telemetry. $461 \quad$ Waterbirds 28(4): 468-477

462 Chick JH, Ruetz III CR, Trexler JC (2004) Spatial scale and abundance patterns of large fish 463 communities in freshwater marshes of the Florida Everglades. Wetlands 24(3): 652-664

464 Childers DL (2006) A synthesis of long-term research by the Florida Coastal Everglades LTER 465 Program. Hydrobiologia 569:531-544 
466 Claudino MC, Abreu PC, Garcia AM (2013) Stable isotopes reveal temporal and between-habitat 467 changes in trophic pathways in a southwestern Atlantic estuary. Mar Ecol Progr Ser 489:29$468 \quad 42$

469 Claudino MC, Pessanha ALM, Araújo FG, Garcia AM (2015) Trophic connectivity and basal 470 food sources sustaining tropical aquatic consumers along a mangrove to ocean gradient. $471 \quad$ Estuar Coast Shelf Sci 167:45-55

472 Colares EP, Waldemarin HF (2000) Feeding of the Neotropical River Otter (Lontra longicaudis) 473 in the Coastal Region of the Rio Grande do Sul State, Southern Brazil IUCN Otter Spec.

$474 \quad$ Group Bull. 17 (1): 6 - 13

475 Cross WF, Baxter CV, Rosi-Marshall EJ, Hall RO, Kennedy TA, Donner KC, Wellard Kelly HA, 476 Seegert SEZ, Behn KE, Yard MD (2013) Food-web dynamics in a large river discontinuum. $477 \quad$ Ecol Monogr 83:311-337

478 DeAngelis DL, Loftus WF, Trexler JC, Ulanowicz RE (1997) Modeling fish dynamics and 479 effects of stress in a hydrologically pulsed ecosystem. J Aquat Ecosyst Stress Recovery 6: 1$480 \quad 13$

481 DeAngelis DL, Trexler JC, Loftus WF (2005) Life history trade-offs and community dynamics 482 of small fishes in a seasonally pulsed wetland. Canadian J Fish Aquat Sci 62: 781-790 483 Flecker AS, Mcintyre PB, Moore JW, Anderson JT, Taylor BW, Hall RO. (2010) Migratory 484 fishes as material and process subsidies in riverine ecosystems. American Fisheries Society $485 \quad$ Symposium 73:559-592

486 Garcia AM, Vieira JP, Winemiller KO (2001) Dynamics of the shallow-water fish assemblage of 487 the Patos Lagoon estuary (Brazil) during cold and warm ENSO episodes. J Fish Biol $488 \quad 59: 1218-1238$ 
Garcia AM, Raseira MB, Vieira JP, Winemiller KO, Grimm AM (2003) Spatiotemporal variation in shallow-water freshwater fish distribution and abundance in a large subtropical coastal lagoon. Environ Biol Fish 68:215-228

492 Garcia AM, Vieira JP, Winemiller KO, Grimm AM (2004) Comparison of the 1982-1983 and 1997-1998 El Niño effects on the shallow-water fish assemblage of the Patos Lagoon estuary (Brazil). Estuaries 27:905-914

Garcia AM, Bemvenuti MA, Vieira JP, Marques DMLM, Burns MDM, Moresco A, Condini MVL (2006) Checklist comparison and dominance patterns of the fish fauna at Taim Wetland, South Brazil. Neotrop Ichthyol 4: 261-268

Garcia AM, Hoeinghaus DJ, Vieira JP, Winemiller KO (2007) Isotopic variation of fishes in freshwater and estuarine zones of a large subtropical coastal lagoon. Estuar Coast Shelf S

504 Garcia AM, Claudino MC, Mont'alverne R, Pereyra PER, Copertino M, Vieira JP (in press) Temporal variability in food assimilation of basal food sources by an omnivorous fish at Patos Lagoon Estuary revealed by stable isotopes (2010-2014). Mar Biol Res $10.1080 / 17451000.2016 .1206939$

Griffiths SP (1999) Consequences of artificially opening coastal lagoons on their fish

510 Hoeinghaus DJ, Vieira JP, Costa CS, Bemvenuti CE, Winemiller KO, Garcia AM (2011) Estuary 511 hydrogeomorphology affects carbon sources supporting aquatic consumers within and among 
512 ecological guilds. Hydrobiologia 673:79-92

513 Holt RD (2008) Theoretical perspectives on resource pulses. Ecology 89:671-681

514 Jardine TD, Pettit NE, Warfe DM, Pusey BJ, Ward DP, Douglas MM, Davies PM. Bunn SE

515 (2012) Consumer-resource coupling in wet-dry tropical rivers. J Anim Ecol 81: 310-322

516 Kaymak N, Winemiller KO, Akin S, Altuner Z, Polat F, Dal T (2015) Stable isotope analysis

517 reveals relative influences of seasonal hydrologic variation and impoundment on assimilation

518 of primary production sources by fish in the Upper Yesilırmak River, Turkey. Hydrobiologia

$519 \quad 753: 131-147$

520 Knak RB (2004) Management plan of Lagoa do Peixe National Park (in Portuguese).

521 IBAMA/FNMA/FURG/ NEMA/UFPel, Brasília. 465 p.

522 Kokkoris GD, Jansen VAA, Loreau M, Troumbis AY (2002) Variability in interaction strength

523 and implications for biodiversity. J Anim Ecol 71:362-371

524 Koshino Y, Kudo H, Kaeriyama M (2013) Stable isotope evidence indicates the incorporation

525 into Japanese catchments of marine-derived nutrients transported by spawning Pacific

526 Salmon. Freshwater Biol 58:1864-1877

527 Krenz C, Menge BA, Freidenburg TL, Lubchenco J, Chan F, Foley MM, Nielsen KJ (2011)

528 Ecological subsidies to rocky intertidal communities: linear or non-linear changes along a

529 consistent geographic upwelling transition? J Exp Mar Biol Ecol 409:361-370

530 Lanés LEK, Rolon AS, Stenert C, Maltchik L (2015) The effects of annual artificial opening of a

531 natural sandbar of a lagoon system on the fish community. J Appl Ichthyol 31:321-327

532 Leibhold A, Koenig WD, Bjørnstad ON (2004) Spatial synchrony in population dynamics.

533 Annual Review of Ecology and Systematics 35:467-490

534 Maltchik L, Lanés LEK, Stenert C, Medeiros ESF (2010) Species-area relationship and 
environmental predictors of fish communities in coastal freshwater wetlands of southern Brazil. Environ Biol Fish 88:25-35

537 Marshall JD, Brooks JR, Lajtha K (2007) Sources of variation in the stable isotopic composition

538 of plants. In: Mitchener R, Lajtha K (eds) Stable isotopes in ecology and environmental

539 science. Blackwell Scientific, Oxford, p 22-60

540 Mattson WJ, Addy ND (1975) Phytophagous insects as regulators of forest primary production.

$541 \quad$ Science 190:515-522

542 McCormick MI (2003) Consumption of coral propagules after mass spawning enhances larval 543 quality of damselfish through maternal effects. Oecologia, 136:37-45

544 Myers GS (1938) Freshwater fishes and West Indian zoogeography. Annual Report of the Board 545 of Regents of the Smithsonian Institution 92: 339-364

546 Naiman RJ, Bilby RE, Schindler DE, Helfied JM (2002) Pacific salmon, nutrients, and the 547 dynamics of freshwater and riparian ecosystems. Ecosystems 5:399-417

548 Nakano S, Murakami M (2001) Reciprocal subsidies: dynamic interdependence between 549 terrestrial and aquatic food webs. P Natl Acad Sci 98:166-170

550 Nakano S, Miyasaka H, Kuhara N (1999) Terrestrial-aquatic linkages: riparian arthropod inputs $551 \quad$ alter trophic cascades in a stream food web. Ecology 80:2435-2441

552 Oliveira MCLM, Bastos RF, Claudino MC, Assumpção CM, Garcia AM (2014) Transport of 553 marine-derived nutrients to subtropical freshwater food webs by juvenile mullets: a case 554 study in southern Brazil. Aquat Biol 20:91-100

555 Ostfeld RS, Keesing F (2000) Pulsed resources and community dynamics of consumers in 556 terrestrial ecosystems. Trends Ecol Evol 15:232-237

557 Ou C, Winemiller KO (2016) Seasonal hydrology shifts production sources supporting fishes in 
rivers of the Lower Mekong Basin. Canadian Journal of Fisheries and Aquatic Sciences, 10.1139/cjfas-2015-0214

Parnell AC, Inger R, Bearhop S, Jackson AL (2010) Source partitioning using stable isotopes:

$561 \quad$ coping with too much variation. PLoS ONE 5:e9672

562 Petersen JK, Hansen JW, Laursen MB, Clausen P, Carstensen J, Conley DJ (2008) Regime shift

563 in a coastal marine ecosystem. Ecol Appl 18(2): 497-510

564

565 Peterson BJ, Fry B (1987) Stable isotopes in ecosystem studies. Annu Rev Ecol Evol Syst

$566 \quad 18: 293-320$

567 Petraitis PS, Latham RE (1999) The importance of scale in testing the origins of alternative 568 community states. Ecology 80:429-442

569 Poff NL, Allan JD, Bain MB, Karr JR, Prestegaard KL, Richter BD, Sparks RE, Stromberg JC

570 (1997) The natural flow regime: a paradigm for river conservation and restoration.

$571 \quad$ Bioscience 47:769-784

572 Polis GA, Power ME, Huxel GR eds. (2004) Food webs at the landscape level. University of $573 \quad$ Chicago Press, Chicago, Illinois, USA.

574 Polis GA, Anderson WB, Holt RD (1997) Toward an integration of landscape and food web 575 ecology: the dynamics of spatially subsidized food webs. Annu Rev Ecol Syst 28:289-316

576 Pratchett MS, Gust N, Goby G, Klanten SO (2001) Consumption of coral propagules represents

577 a significant trophic link between corals and reef fish. Coral Reefs 20:13-17

578 Rolon AS, Rocha O, Maltchick L (2011) Diversity of aquatic macrophytes in the Lagoa do Peixe $579 \quad$ National Park. Neotrop Biol Conserv 6(1):5-12

580 Rozas LP, Minello TJ (1997) Estimating densities of small fishes and decapod crustaceans in 
shalow estuarine habitats: a review of sampling design with focus on gear selection. Estuaries, 20: 199-213

583 Saad AM, Beaumond AC, Caramaschi EP (2002) Effects of artificial canal openings on fish 584 community structure of Imboassica coastal lagoon, Rio de Janeiro, Brazil. J Coastal Res $585 \quad 36: 634-639$

586 Savage C, Thrush SF, Lohrer AM, Hewitt JE (2012) Ecosystem services transcend 587 boundaries: estuaries provide resource subsidies and influence functional diversity in coastal benthic communities. PLoS ONE: 7:e42708.

589 Spiller DA, Piovia-Scott J, Wright AN, Yang LH, Takimoto G, Schoener TW, Iwata T

590 (2010) Marine subsidies have multiple effects on coastal food webs. Ecology 91:1424-

$591 \quad 1434$

592 Vanderklift MA, Ponsard S (2003) Sources of variation in consumer-diet d15N enrichment: a 593 meta-analysis. Oecologia 136:169-182

594 Warfe DM, Pettit NE, Davies PM, Pusey BJ, Hamilton SK, Kennard MJ, Townsend SA, Bayliss

595 P, Ward DP, Douglas MM, Burford MA, Finn M, Bunn SE, Halliday IA (2011) The 'wet596 dry' in the wet-dry tropics drives ecosystem structure and function of northern Australian $597 \quad$ rivers. Freshw Biol 56: 2169-2195

598 Winemiller KO (1990) Spatial and temporal variation in tropical fish trophic networks. Ecol 599 Monogr 60:331-367Winemiller KO, Layman CA (2005) Food web science: moving on the 600 path from abstraction to prediction. In: Ruiter PC, Wolters V, Moore JC (eds) Dynamic Food 601 Webs: Multispecies Assemblages, Ecosystem Development and Environmental Change. 602 Elsevier, Amsterdam, Netherlands, p 10-23 
603 Yang LH (2004) Periodical cicadas as resource pulses in North American forests. Science $604 \quad 306: 1565-1567$

605 Yang LH, Bastow JL, Spence KO, Wright AN (2008) What can we learn from resource pulses?

$606 \quad$ Ecology 89:621-634

607 Zackrisson O, Nilsson MC, Jaderlund A, Wardle DA (1999) Nutritional effects of seed fall 608 during mast years in boreal forest. Oikos 84:17-26

609 Zar JH (1984) Biostatistical analysis. 2nd ed. Prentice-Hall, Englewood Cliffs, New Jersey, USA 610 


\section{$611 \quad$ Figure and legends}

612 Figure 1. Upper. Panel. Map showing the Lagoa do Peixe National Park (LPNP) in the coastal

613 plain of southern Brazil with the location of the sampled areas (squares) at the freshwater

614 wetland (1), at the estuarine zone (2) and at the lagoon's mouth (3). Red dashed line denotes the

615 boundaries of the national park. Pictures taken at the mouth of the lagoon on April $2^{\text {th }}$ and

616 November $11^{\text {th }} 2008$ showing the status of its connection with the sea $(C$ and $D)$ and in the same

617 location of the estuarine zone showing the flooded (A) and non-flooded conditions (B). Photos

618 by A.M.Garcia. Lower panel. Monthly variation in rainfall (mm, bars) and water temperature $\left({ }^{\circ} \mathrm{C}\right.$,

619 line) during the study period (April 2008 - May 2009).

621 Figure 2. Mean (+SD) of $\delta^{15} \mathrm{~N}$ and $\delta^{13} \mathrm{C}$ values for primary producers and organic sources (open

622 circles numbered 1 to 4), prey and fishes (left panel) and relative contributions of basal food

623 sources $\left(\mathrm{C}_{3}\right.$ and $\mathrm{C}_{4}$ plants, seston and microphytobentos-MiPhBe) to fishes at the freshwater

624 wetland, estuarine zone and lagoon mouth sites (right panel).

626 Figure 3. Monthly variation in the $\delta^{15} \mathrm{~N}$ and $\delta^{13} \mathrm{C}$ values for fish guilds (primary freshwater-

627 open circles; secondary freshwater- open triangles; estuarine dependent- grey circles; estuarine

628 resident- grey triangles; marine vagrants- dark squares) from the freshwater wetland, estuarine

629 zone and lagoon mouth. Vertical bar on the right denotes flood status within the estuarine zone.

631 Figure 4. Monthly relative contributions of basal food sources $\left(\mathrm{C}_{3}\right.$ and $\mathrm{C}_{4}$ plants, seston and 632 microphytobentos) to biomass of estuarine-resident fish (Atherinella brasiliensis, Odonthestes 633 argentinensis) (left panel) and primary freshwater fish (Astyanax eigenmanniorum, A. fasciatus, 
634 Cheirodon interruptus, Phalloceros caudimaculatus) from the estuarine zone during flooding

635 and non-flooding conditions. Each plot shows the 50 (black), 75 (gray) and 95\% (lighter gray)

636 Bayesian credibility intervals of the feasible contributions of each basal production source to fish

637 in each month.

638

639

640

641

642 


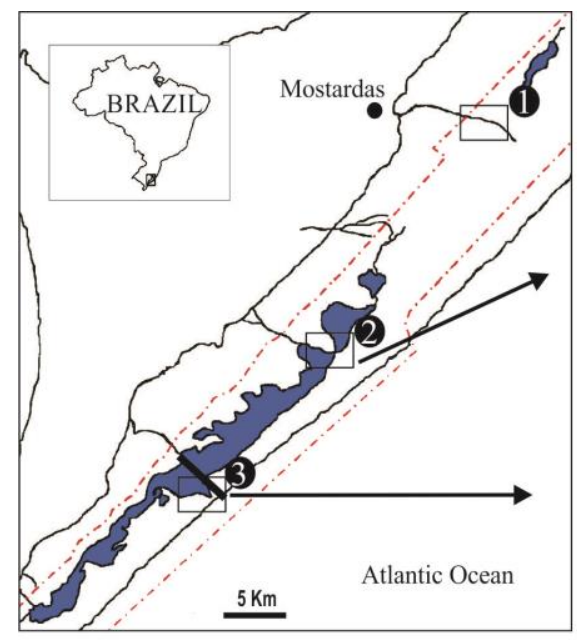

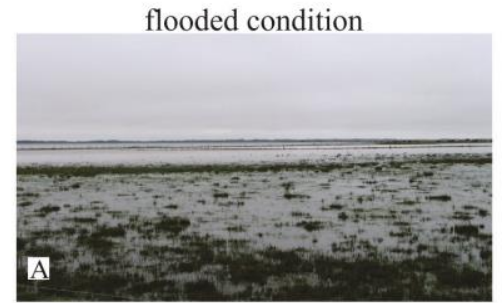

lagoon mouth closed

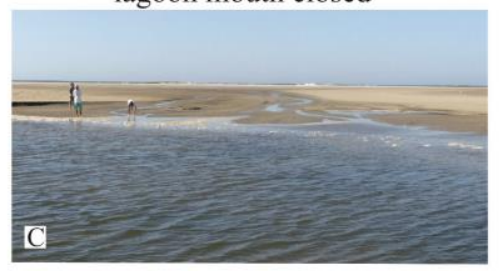

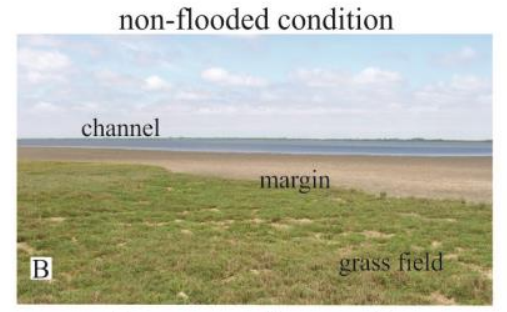

lagoon mouth opened

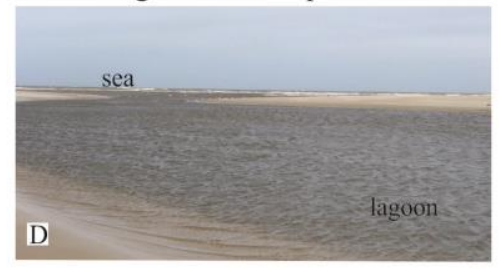

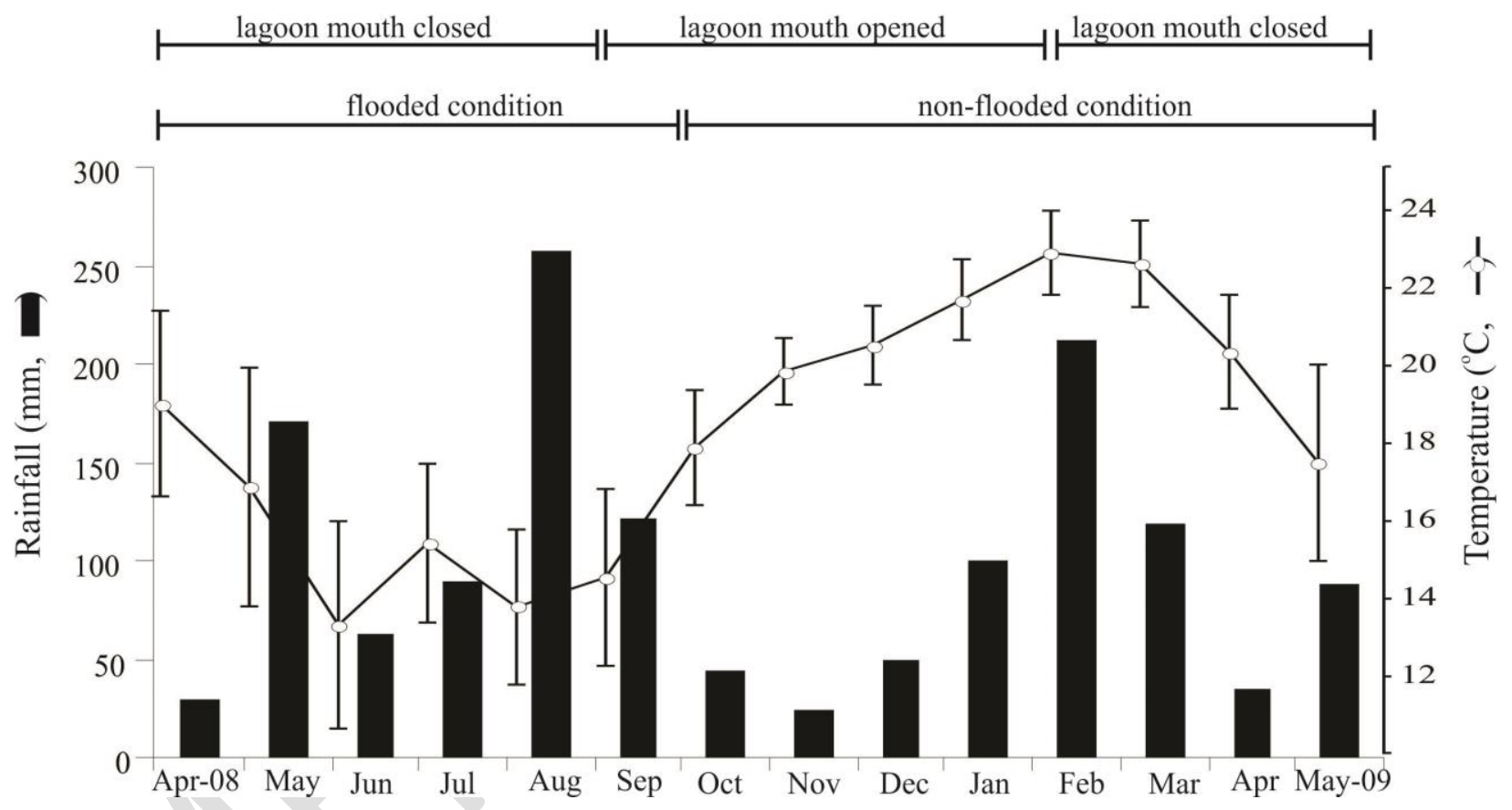

644

645

Figure 1

646

647 

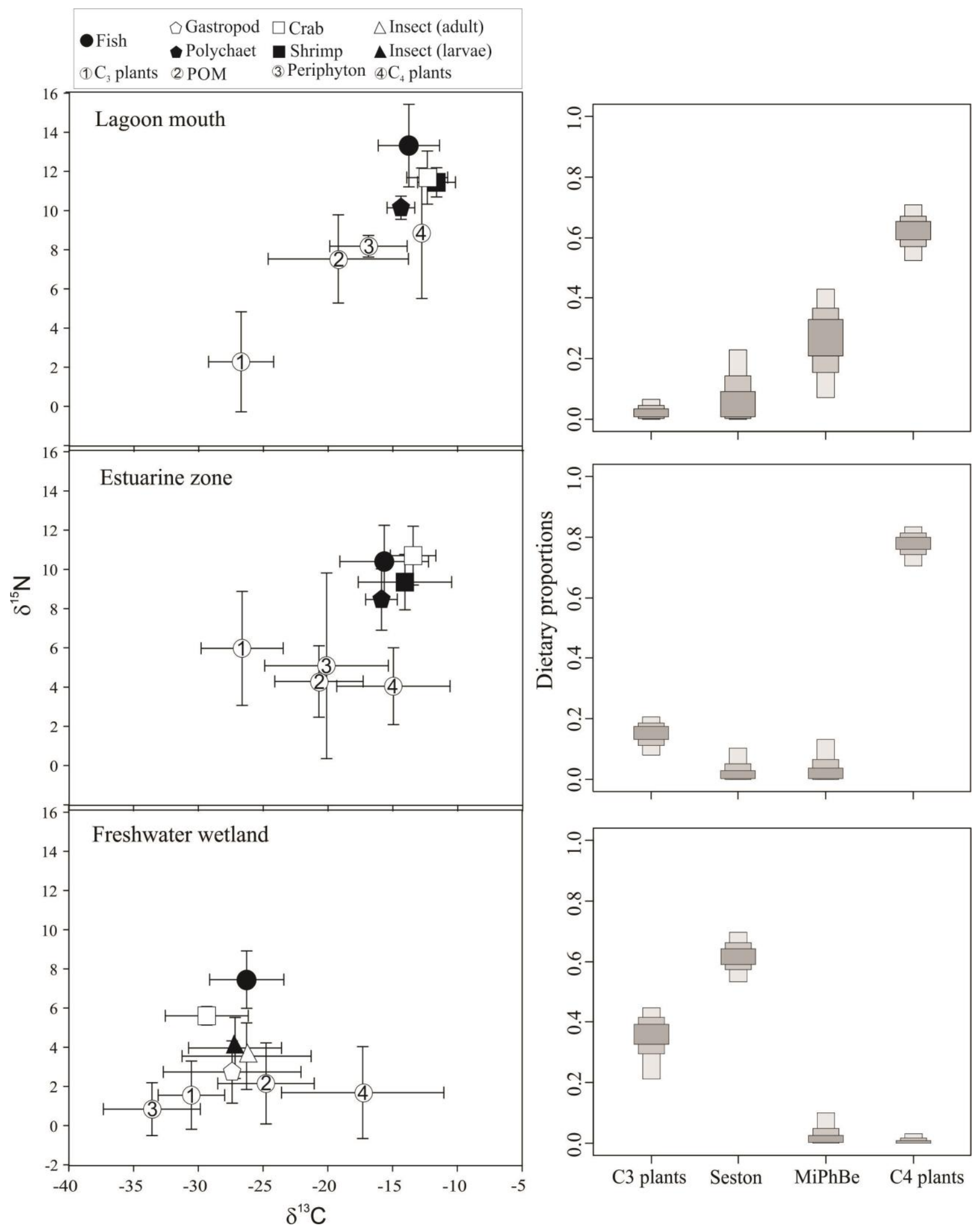

648 $\delta^{13} \mathrm{C}$

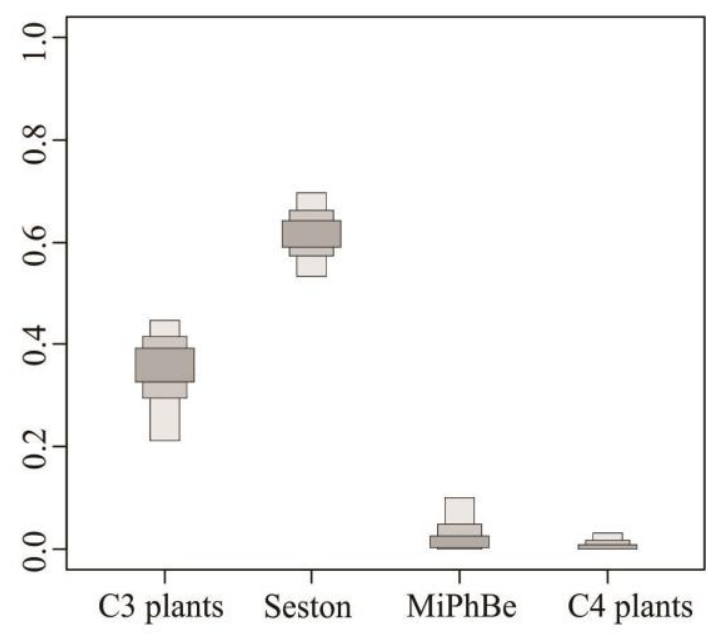


651
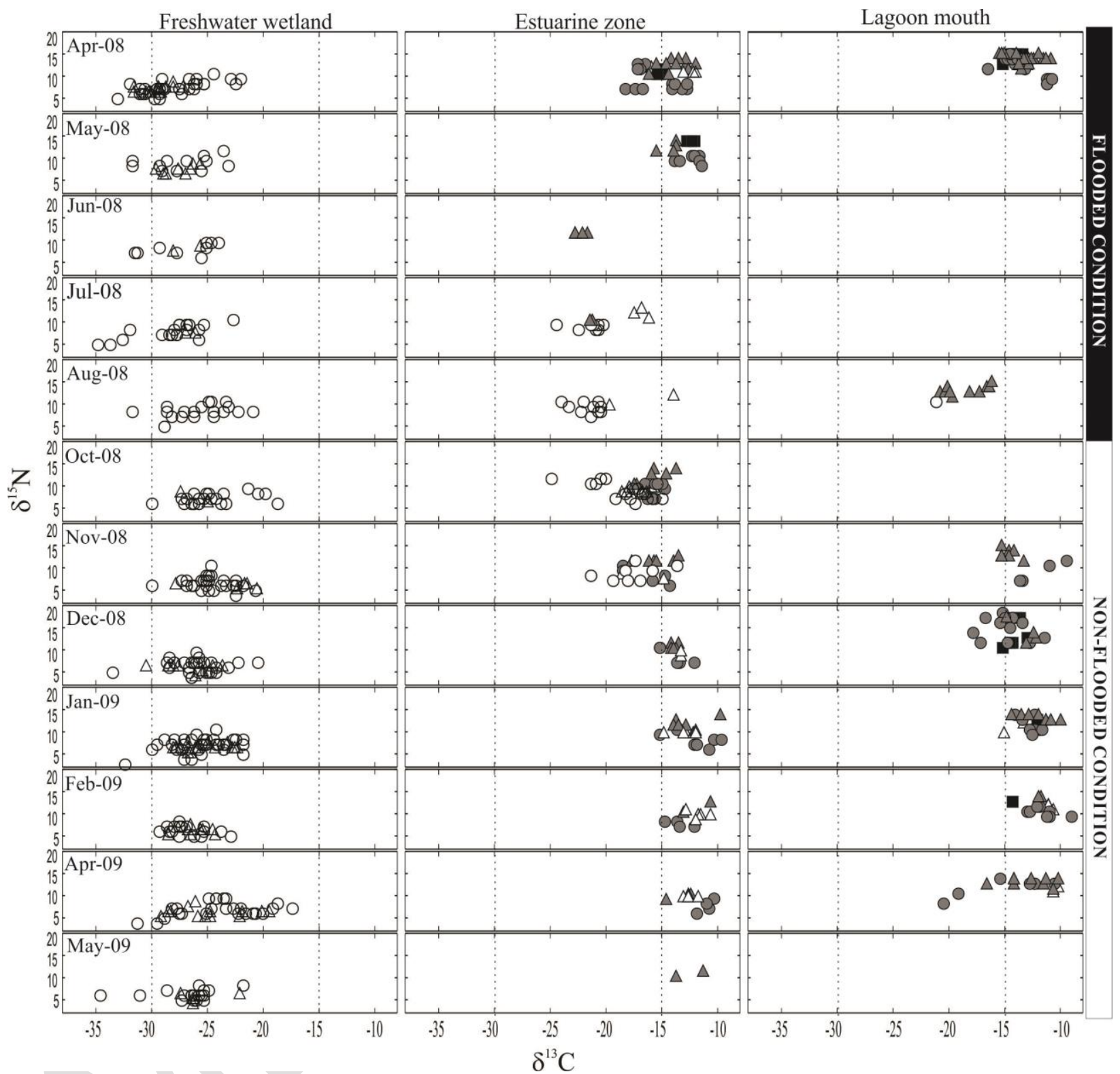

652

Figure 3

654 

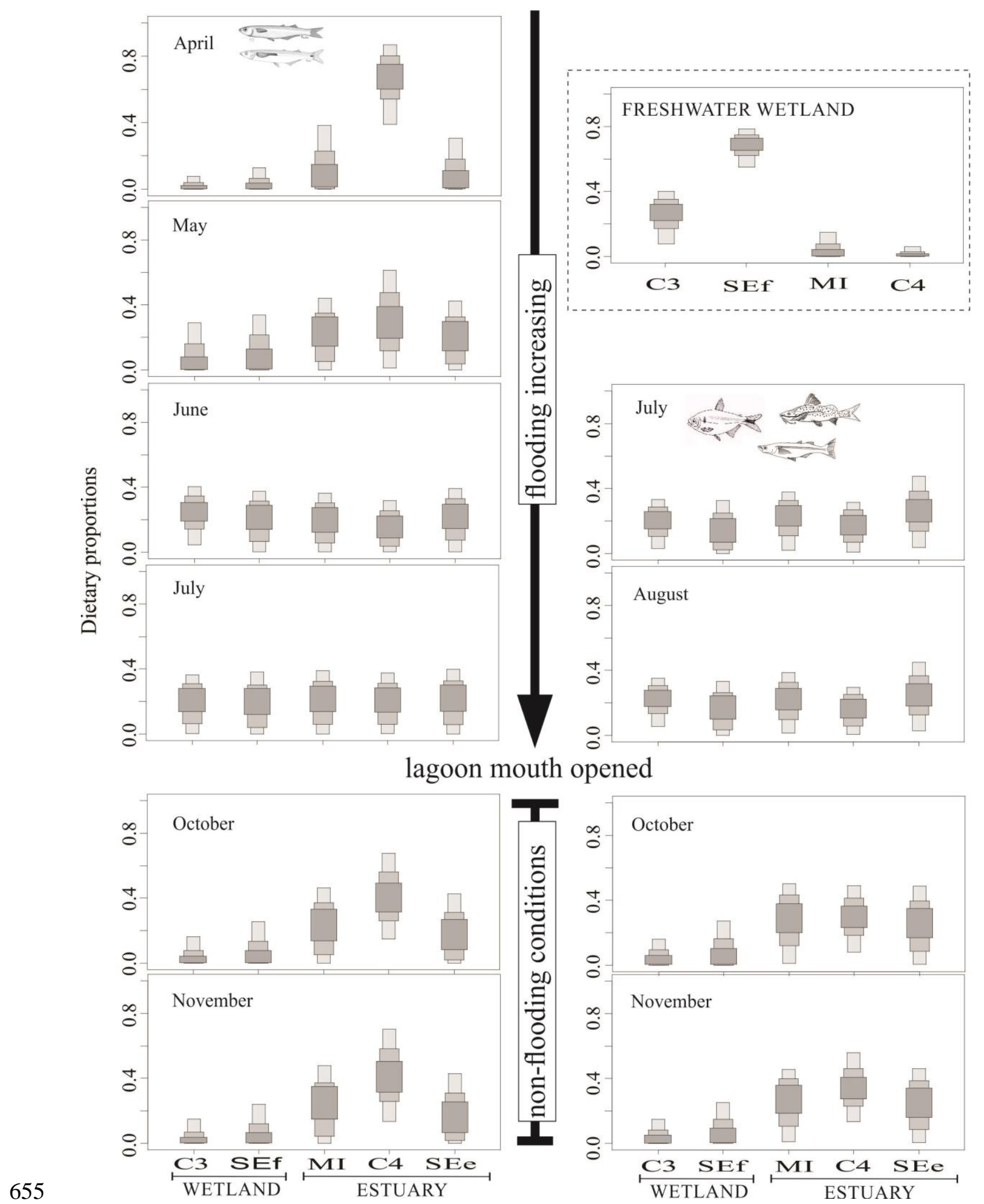

656 Figure 4 


\section{Supplemental material}

661 Appendix A. $\delta^{13} \mathrm{C}$ and $\delta^{15} \mathrm{~N}$ values $(\mathrm{X} \pm \mathrm{SD})$ and total length (TL, $\left.\mathrm{mm}\right)$ of fishes, invertebrates and 662 plants and organic sources at the freshwater wetland, estuarine zone and lagoon mouth of the 663 Lagoa do Peixe National Park. n, sample size. Functional guilds (GUI): primary freshwater (PF), 664 secondary freshwater (SF), estuarine resident (ER), estuarine dependent (ED), marine vagrants 665 (MV).

666

667 Appendix B. Monthly variation in the $\delta^{15} \mathrm{~N}$ and $\delta^{13} \mathrm{C}$ values for basal food sources

668 (microphytobenthos, open circles; seston, open triangles; $\mathrm{C}_{3}$ plants, grey circles; $\mathrm{C}_{4}$ plants) at the 669 freshwater wetland, estuarine zone and lagoon mouth sites. Vertical bar on the right denotes 670 status of the flooding conditions in the estuarine zone. 
Table S1 $-\delta^{13} \mathrm{C}$ and $\delta^{15} \mathrm{~N}$ values $(\mathrm{X}+\mathrm{SD})$ and total length $(\mathrm{TL}, \mathrm{mm})$ of fishes, invertebrates and plants and organic sources at the freshwater wetland, estuarine zone and lagoon mouth of teh Lagoa do Peixe National Park. n, sample size. Functional guilds (GUI): primary freshwater (PF), secondary freshwater (SF), estuarine resident (ER), estuarine dependent (ED), marine vagrants (MV).

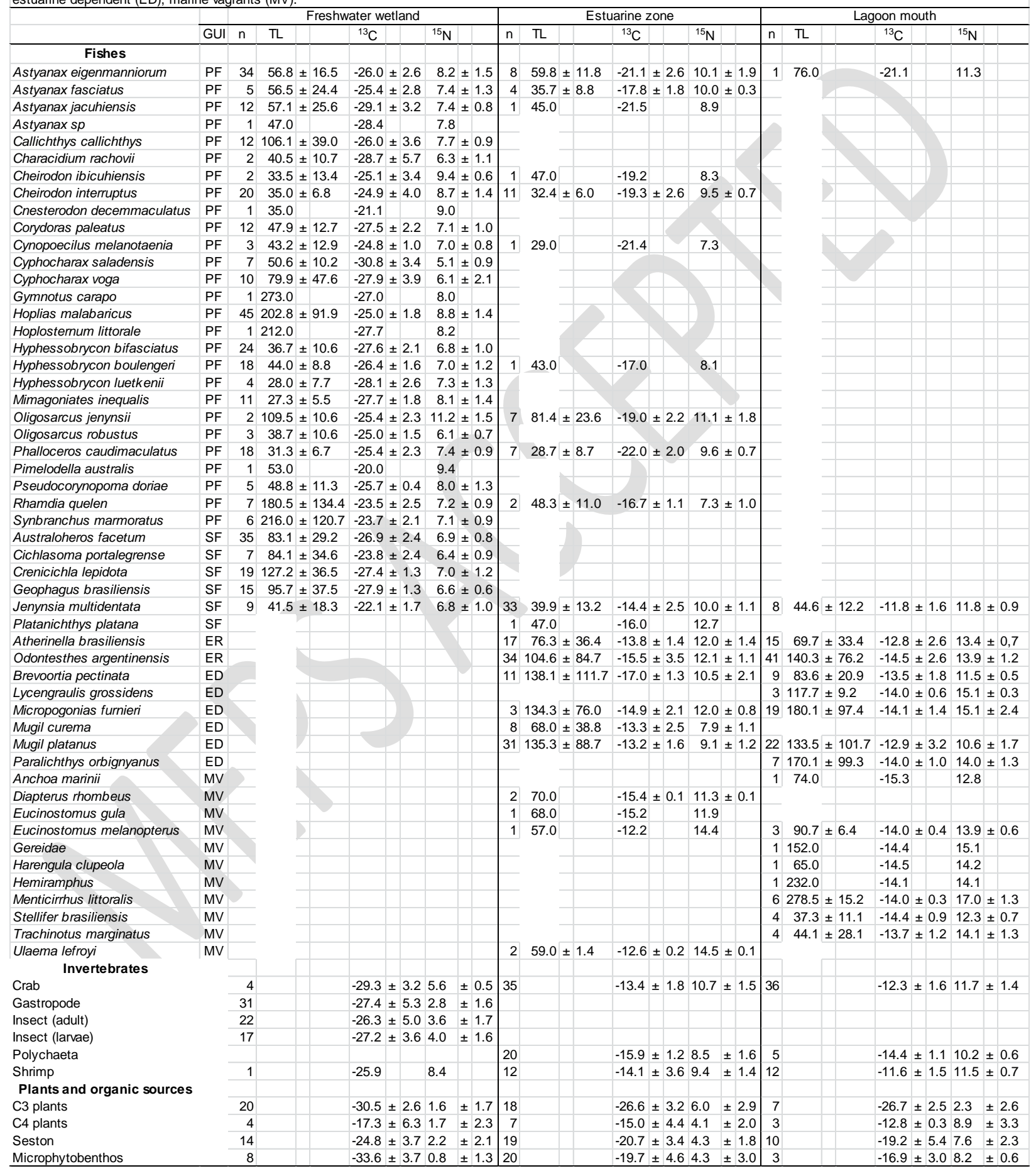


676

677

678

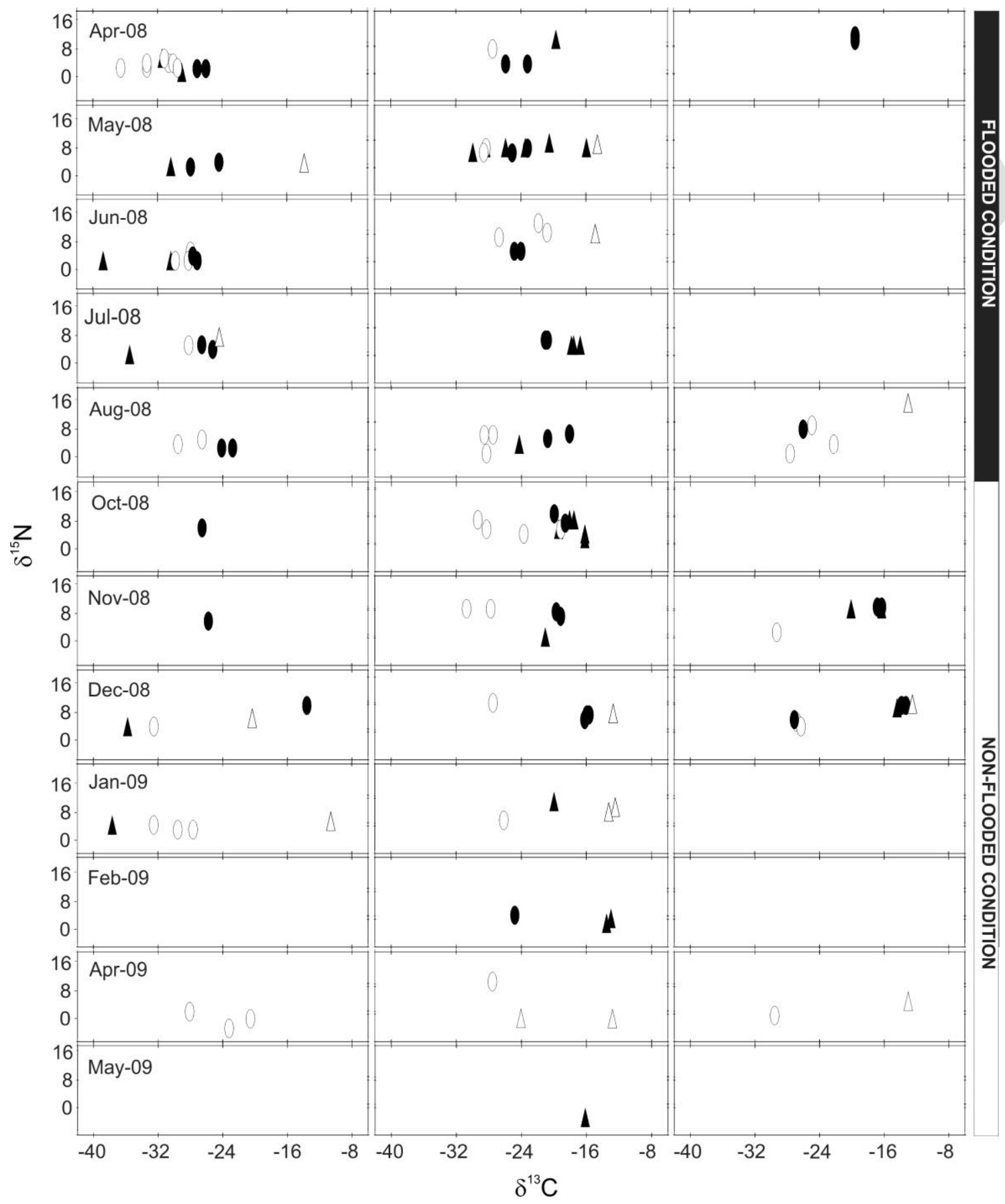

SUPPLEMENTAL MATERIAL

\section{Appendix B}

